\title{
Analisis Kondisi Sosial Ekonomi Orang Tua terhadap Tingkat Pendidikan Anak di
}

\section{Kabupaten Jember}

\author{
Abstract \\ Neviyani, Mucharom \\ IKIP PGRI Jember
}

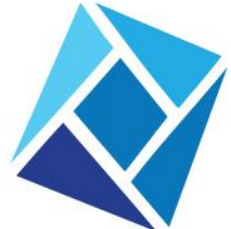

\section{Jurnal Nusantara Aplikasi Manajemen Bisnis}

http://ojs.unpkediri.ac.id/index. $\mathrm{php} / \mathrm{manajemen/index}$

E-ISSN : 2528-0929

P-ISSN : $2549-5291$

Diterima: 31 Maret 2018

Revisi : 16 April 2018

Disetujui: 18 April 2018

https:doi.org10.29407nusamba.v3i 1.11797

\section{Abstrak}

Resource-quality showed the strong commitment of the government in its economic development program, the demands of society were more complex and competition tight, especially in the era of globalization and so that free trade, it needed good quality of human resources, one of effort to improve human resources were through education. This research was conducted in Jember regency, the method for sampling by purposive sampling technique. The data Analysis Technique used Multiple Linear Regression. Based on the calculation results of SPSS, found: 1). There was the influence of social-economic condition level of parents foward education level of children in Jember regency. 2). There was the influence of parents education level toward children education level in Jember regency. 3). There was the influence of parents income to the level of education of children in Jember regency. 4). There was the influence ownership toward the level education of children in Jember regency. 5). There was the influence of hause type the level toward of children education in Jember regency.

Keywords: Socio-economic, education level, income, ownership Facilities wealth, and type Dwelling

Abstrak

Sumberdaya yang berkualitas menunjukkan adanya komitmen yang kuat dari pemerintah dalam program pembangunan ekonominya, tuntutan masyarakat semakin kompleks dan persainganpun semakin ketat, apalagi dalam menghadapi era globalisasi dan perdagangan bebas, untuk itu perlu disiapkan sumber daya manusia yang berkualitas, salah satu upaya meningkatkan sumber daya manusia adalah melalui jalur pendidikan. Penelitian ini dilaksanakan di Kabuapten Jember, metode pengambilan sampel dengan teknik purposive sampling. Teknik Analisa Data menggunakan Regresi Linier Berganda. Berdasarkan hasil perhitungan SPSS, ditemukan : 1). Ada pengaruh kondisi sosial ekonomi orang tua terhadap tingkat pendidikan anak di Kabupaten Jember. 2). Ada pengaruh tingkat pendidikan orang tua terhadap tingkat pendidikan anak di Kabupaten Jember. 3). Ada pengaruh pendapatan orang tua terhadap tingkat pendidikan anak di Kabupaten Jember. 4). Ada pengaruh kepemilikan fasilitas terhadap tingkat pendidikan anak di Kabupaten Jember. 5). Ada pengaruh jenis tempat tinggal terhadap tingkat pendidikan anak di Kabupaten Jember.

Kata Kunci : Sosial Ekonomi, Tingkat Pendidikan, Pendapatan, Kepemilikan Fasilitas / kekayaan, dan Jenis Tempat Tinggal 


\section{Pendahuluan}

Sumberdaya yang berkualitas menunjukkan adanya komitmen yang kuat dari pemerintah dalam program pembangunan ekonominya. Komitmen yang kuat ini dapat ditujukan dengan anggaran dan subsidi yang besar untuk pembangunan sumberdaya manusia, tuntutan masyarakat semakin kompleks dan persainganpun semakin ketat, apalagi dalam menghadapi era globalisasi dan perdagangan bebas, untuk itu perlu disiapkan sumber daya manusia yang berkualitas, salah satu upaya meningkatkan sumber daya manusia adalah melalui jalur pendidikan.

Berdasarkan data Badan Pusat Statistik Kabupaten Jember ${ }^{1}$, jumlah penduduk dan kepadatan penduduk menurut kecamatan sejumlah 2.332.726, dan jumlah penduduk terbanyak terletak pada Kabupaten Jember sejumlah 126.279, dari 31 Kecamatan dengan sebaran pendidikan yang di tamatkan sejumlah 85.822, dari tamatan SD sejumlah 25.405, tamatan SMP 14.014, tamatan SLTA 33.910, tamatan D1/D2/D3 sejumlah 2.859 dan tamatan Perguruan Tinggi sejumlah 9.634.

Beberapa penelitian yang pernah dilakukan, diantaranya Reddy Zaki Oktama ${ }^{2}$. Pengaruh Kondisi Sosial Ekonomi Terhadap Tingkat Pendidikan Anak Keluarga Nelayan Di Kelurahan Sugihwaras Kecamatan Pemalang Kabupaten Pemalang Tahun 2013. Hasil penelitiannya adalah : 1). Terdapat pengaruh yang signifikan antara kondisi sosial keluarga terhadap tingkat pendidikan anak nelayan sebesar 5,8\%, artinya variasi kondisi sosial mampu menjelaskan variasi tingkat pendidikan anak sebesar 5,8\%. Maka semakin tinggi kondisi sosial keluarga akan semakin tinggi pula tingkat pendidikan anaknya. 2). Terdapat pengaruh yang signifikan antara kondisi ekonomi keluarga terhadap tingkat pendidikan anak nelayan sebesar $12,1 \%$, artinya variasi kondisi ekonomi mampu menjelaskan variasi tingkat pendidikan anak sebesar 12,1\%. Maka semakin tinggi kondisi ekonomi keluarga akan semakin tinggi pula tingkat pendidikan anaknya. 3). Kondisi sosial ekonomi berpengaruh sebesar $23,2 \%$ artinya kondisi sosial ekonomi secara bersama-sama berpengaruh sebesar 23,2\% terhadap tingkat pendidikan anak di Kelurahan Sugihwaras Kecamatan Pemalang sedangkan sisanya 76,8\% merupakan faktor lain seperti aksesbilitas, motivasi, lingkungan dan masih banyak lagi yang tidak masuk dalam penelitian ini. Salmah ${ }^{3}$. Pengaruh Status Sosial Ekonomi Keluarga Terhadap Motivasi Melanjutkan Ke Perguruan Tinggi di Mas Pontianak. Hasil penelitiannya adalah Status sosial ekonomi di lingkungan keluarga pada siswa Madrasah Aliyah Swasta se-Kota Pontianak termasuk kategori cukup dengan persentase 52,12\%. Motivasi melanjutkan ke perguruan tinggi pada siswa kelas XII madrasah aliyah swasta se- Kota Pontianak termasuk kategori sangat tinggi dengan persentase 84,90\%. Terdapat pengaruh positif status sosial ekonomi di lingkungan keluarga terhadap motivasi melanjutkan pendidikan ke perguruan tinggi pada siswa kelas XII madrasah aliyah swasta se-Kota Pontianak. Berdasarkan t hitung sebesar 3.326 menunjukkan bahwa ada pengaruh variabel bebas (X) terhadap variabel terikat (Y) jika dibandingkan dengan t tabel pada taraf signifikan 95\% sebesar 1.657 maka $t$ hitung lebih besar daripada t tabel atau $(3,326>1,657)$ sehingga Ha diterima dan Ho ditolak. dengan 
Koefisien Determinasi pada penelitian ini menunjukkan kontribusi pengaruh variabel bebas (X) yaitu pengaruh status sosial ekonomi di lingkungan keluarga terhadap variabel terikat (Y) yaitu motivasi melanjutkan ke perguruan tinggi sebesar 8,4\%, sedangkan sisanya dipengaruhi oleh variabel lain.

Tujuan dari penelitian ini adalah Ingin mengetahui adakah pengaruh kondisi sosial ekonomi orang tua terhadap tingkat pendidikan anak di Kecamatan Sumbersari.

Hipotesis dalam penelitian ini adalah :

$\mathrm{Ha}=1$. Ada pengaruh kondisi sosial ekonomi orang tua terhadap tingkat pendidikan anak di Kabupaten Jember.

2. Ada pengaruh tingkat pendidikan orang tua terhadap tingkat pendidikan anak di Kabupaten Jember.

3. Ada pengaruh pendapatan orang tua terhadap tingkat pendidikan anak di Kabupaten Jember.

4. Ada pengaruh kepemilikan fasilitas / kekayaan terhadap tingkat pendidikan anak di Kabupaten Jember.

5. Ada pengaruh jenis tempat tinggal terhadap tingkat pendidikan anak di Kabupaten Jember.

Ho $=1$ Tidak ada pengaruh kondisi sosial ekonomi orang tua terhadap tingkat pendidikan anak di Kabupaten Jember

2. Tidak ada pengaruh tingkat pendidikan orang tua terhadap tingkat pendidikan anak di Kabupaten Jember.

3. Tidak ada pengaruh pendapatan orang tua terhadap tingkat pendidikan anak di Kabupaten Jember.

4. Tidak ada pengaruh kepemilikan fasilitas / kekayaan terhadap tingkat pendidikan anak di Kabupaten Jember.

5. Tidak ada pengaruh jenis tempat tinggal terhadap tingkat pendidikan anak di Kabupaten Jember.

\section{METODE PENELITIAN}

Penelitian ini merupakan penelitian penjelasan (Explanatory research) yang menjelaskan hubungan kausal antara variabel laten eksogen dan variabel laten endogen melalui pengujian hipotesis. Lokasi penelitian adalah di Kabupaten Jember. Populasi penelitian menggunakan metode purposive area. Popolasi dalam penelitian ini adalah keluarga di Kabupaten Jember dan metode pengambilan sampel dengan teknik purposive sampling, maka sampel yang diambil sejumlah 200. 


\section{TEKNIK ANALISIS DATA}

\section{Metode Pengujian Data}

\section{a. Uji Validitas}

Uji validitas dilakukan guna memastikan akuransi alat ukur yang digunakan. Validitas item pertanyaan dalam penelitian ini menggunakan teknik korelasi Product Moments yang merupakan korelasi antara skor item pertanyaan dengan total skor item pertanyaan yang digunakan untuk menguji validitas instrumen. Kriteria setiap item pertanyaan dinyatakan valid apabila nilai $r$ (koefisien korelasi antara skor butir pertanyaan dengan total skor) $>0,30$ (Sarwono $\left.{ }^{4}, 2009: 185\right)$.

\section{b. Uji Reliabilitas}

Reliabilitas erat hubungannya dengan kepercayaan. Suatu tes dikatakan mempunyai taraf kepercayaan jika tes memberikan hasil yang tepat. Dalam penelitian ini, peneliti menggunakan alat uji reliabilitas data menggunakan rumus alpha cronbach $(\alpha)$ didasarkan pada konsistensi internal suatu instrumen penelitian. Nilai alpha cronbach $(\alpha)$ untuk data reliabel > 0,6 (Sugiyono ${ }^{5}, 2010: 153$ )

\section{Uji Asumsi Klasik}

Uji asumsi klasik terdiri dari :

\section{a. Uji Normalitas}

Dasar pengambilan keputusan pada uji normalitas dengan kriteria jika data menyebar disekitar garis diagonal dan mengikuti arah garis diagonal, maka model analisis data yang ada memenuhi asumsi normalitas.

\section{b. Uji Multikolinieritas}

Pengambilan keputusan pengujian dilakukan dengan kriteria jika nilai condition index < nilai 15 maka tidak terjadi multikolinieritas.

\section{Analisis Data dan Pengujian Hipotesis}

1. Analisis Regresi Berganda

Analisis yang digunakan untuk menguji hipotesis dalam penelitian ini adalah analisis regresi linier berganda diaplikasikan dengan menggunakan SPSS, Analisis Regresi Berganda :

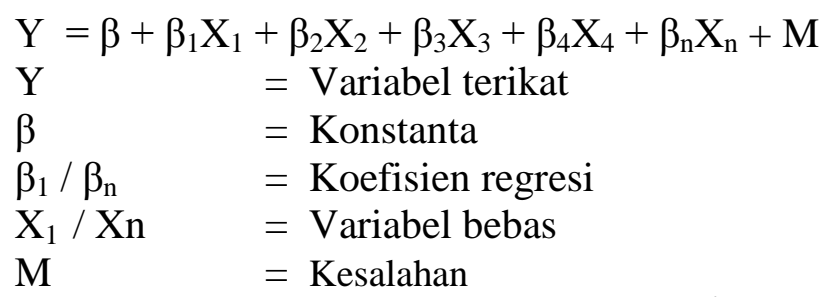

( Damodar Gujarati dalam Sutrisno Djaja ${ }^{6}, 2004: 41$ ) 


\section{Analisis F- Test}

Analisa hipotesa F-Test merupakan hipotesa berdasarkan hasil penyelidikan lebih dari dua sample. Sebagai gambaran misalnya kita akan menyelidiki apakah perbedaan mean sample utama dengan sample kedua, ketiga itu disebabkan oleh faktor yang kebetulan saja atau faktor lain yang benar-benar berarti (signifikan).

Adapun langkah-langkah dalam pengujian adalah sebagai berikut :

1. Ketentuan hipotesa adalah :

- Ho : $b_{1}=b_{2}=b_{3}=b_{4>}=0$, Artinya secara bersama-sama variable bebas idak mempunyai pengaruh yang positif terhadap variable terikat

- $\quad$ Ho $: b_{1} \neq b_{2} \neq b_{3} \neq b_{4}><0$, Artinya secara bersama-sama variable bebas mempunyai pengaruh yang positif terhadap variable terikat

2. Menentukan level of significant $(a=0,10)$ dengan pertimbangan bahwa data yang diperoleh memiliki derajat keyakinan sampai dengan $90 \%$.

3. Menghitung nilai $\mathrm{F}$ dengan rumus :

$$
F=\frac{R^{2} / k}{\left(1-R^{2}\right)(n-k-1)}
$$

( Damodar Guyarati dalam Sutrisno Djaja ${ }^{7}, 2004:$ 41)

4. Kriteria pengujian :

- Apabila : F hit < F table, maka Ho diterima dan Ha ditolak, berarti tidak terdapat pengaruh / hubungan yang kuat antara variabel bebas (X) dengan Variabel terikat (Y).

- Apabila : F hit > F table, maka maka Ho ditolak dan Ha diterima, berarti terdapat pengaruh / hubungan yang kuat antara variabel bebas (X) dengan Variabel terikat (Y).

\section{Analisis T-Test}

Test hipotesa ini digunakan untuk mengup secara individual mengenai pengaruh dari variabel independent terhadap variabel dependent. Prosedur pengujian adalah sebagai berikut :

- $\quad$ Ho : $\mathrm{B}=0$, berarti tidak berpengaruh positif antara variabel terikat dan variable bebas

- $\quad$ Ho : $\mathrm{B}=0$, berarti berpengaruh positif antara variable terikat dan variable bebas, derajat keyakinan dari data yang diperoleh adalah $90 \%$ sehingga $a=0,10$

Uji statistiknya $\quad t=r \sqrt{\frac{N-K-1}{1-r^{2}}}$

(Anto Dayan dalam Sutrisno Djaja $\left.{ }^{8}, 2004: 41\right)$

- Apabila : $\mathrm{t}$ hit < t table, maka Ho diterima dan Ha ditolak, berarti tidak terdapat pengaruh / hubungan yang positif antara variabel bebas (X) dengan Variabel terikat (Y). 
- Apabila : $\mathrm{t}$ hit > t table, maka maka Ho ditolak dan Ha diterima, berarti terdapat pengaruh / hubungan yang positif antara variabel bebas (X) dengan Variabel terikat (Y).

\section{HASIL DAN PEMBAHASAN}

\section{Hasil Pengujian Data}

a. Hasil Uji Validitas dan Reliabilitas Variabel Tingkat Pendidikan (X1)

Hasil uji validitas variabel tingkat pendidikan (X1) dapat diperoleh nilai koefisien korelasi sebesar 0,355;0,766;0,865; 0,642. Nilai koefisien korelasi yang diperoleh dari hasil uji validitas lebih besar dari nilai minimal koefisien korelasi yaitu 0,300. Berdasarkan kriteria yang ada, maka data dinyatakan valid.

Hasil uji reliabilitas variabel tingkat pendidikan (X1) dapat diperoleh nilai Alpha Cronbach sebesar 0,763. Nilai Alpha Cronbach yang diperoleh dari hasil uji reliabilitas lebih besar dari nilai minimal Alpha Cronbach yaitu 0,600. Berdasarkan kriteria yang ada, maka data dinyatakan reliabel.

b. Hasil Uji Validitas dan Reliabilitas Variabel Pendapatan (X2)

Hasil uji validitas variabel pendapatan (X2) dapat diperoleh nilai koefisien korelasi sebesar 0,$820 ; 0,806 ; 0,664$. Nilai koefisien korelasi yang diperoleh dari hasil uji validitas lebih besar dari nilai minimal koefisien korelasi yaitu 0,300. Berdasarkan kriteria yang ada, maka data dinyatakan valid.

Hasil uji reliabilitas variabel pendapatan (X2) dapat diperoleh nilai Alpha Cronbach sebesar 0,807. Nilai Alpha Cronbach yang diperoleh dari hasil uji reliabilitas lebih besar dari nilai minimal Alpha Cronbach yaitu 0,600. Berdasarkan kriteria yang ada, maka data dinyatakan reliabel.

c. Hasil Uji Validitas dan Reliabilitas Variabel Tingkat Kepemilikan Fasilitas/Kekayaan (X3)

Hasil uji validitas variabel tingkat kepemilikan fasilitas/ kekayaan (X3) dapat diperoleh nilai koefisien korelasi sebesar 0,750;0,803;0,721. Nilai koefisien korelasi yang diperoleh dari hasil uji validitas lebih besar dari nilai minimal koefisien korelasi yaitu 0,300. Berdasarkan kriteria yang ada, maka data dinyatakan valid.

Hasil uji reliabilitas variabel tingkat kepemilikan fasilitas/ kekayaan (X3) dapat diperoleh nilai Alpha Cronbach sebesar 0,805. Nilai Alpha Cronbach yang diperoleh dari hasil uji reliabilitas lebih besar dari nilai minimal Alpha Cronbach yaitu 0,600. Berdasarkan kriteria yang ada, maka data dinyatakan reliabel.

d. Hasil Uji Validitas dan Reliabilitas Variabel Jenis Tempat Tinggal (X4)

Hasil uji validitas variabel jenis tempat tinggal (X4) dapat diperoleh nilai koefisien korelasi sebesar 0,509;0,802;0,816;0,184. Nilai koefisien korelasi dari hasil uji validitas yang lebih besar dari nilai minimal koefisien korelasi yaitu 0,300 dinyatakan valid, sedangkan nilai yang lebih kecil dari 0,300 
dinyatakan tidak valid. Data yang dinyatakan tidak valid, kemudian tidak diproses lebih lanjut. Sedangkan data yang dinyatakan valid, akan diproses lebih lanjut.

Hasil uji reliabilitas variabel jenis tempat tinggal (X4) dapat diperoleh nilai Alpha Cronbach sebesar 0,732. Nilai Alpha Cronbach yang diperoleh dari hasil uji reliabilitas lebih besar dari nilai minimal Alpha Cronbach yaitu 0,600. Berdasarkan kriteria yang ada, maka data dinyatakan reliabel.

\section{e. Hasil Uji Validitas dan Reliabilitas Variabel Tingkat Pendidikan Anak (Y)}

Hasil uji validitas variabel tingkat pendidikan anak (Y) dapat diperoleh nilai koefisien korelasi sebesar 0,170;0,338;0,646;0,906. Nilai koefisien korelasi dari hasil uji validitas yang lebih besar dari nilai minimal koefisien korelasi yaitu 0,300 dinyatakan valid, sedangkan nilai yang lebih kecil dari 0,300 dinyatakan tidak valid. Data yang dinyatakan tidak valid, kemudian tidak diproses lebih lanjut. Sedangkan data yang dinyatakan valid, akan diproses lebih lanjut.

Hasil uji reliabilitas variabel tingkat pendidikan anak (Y) dapat diperoleh nilai Alpha Cronbach sebesar 0,696. Nilai Alpha Cronbach yang diperoleh dari hasil uji reliabilitas lebih besar dari nilai minimal Alpha Cronbach yaitu 0,600. Berdasarkan kriteria yang ada, maka data dinyatakan reliabel.

Setelah data dinyatakan valid dan reliabel, maka data diuji normalitasnya, hasil uji normalitas data dijelaskan sebagai berikut :

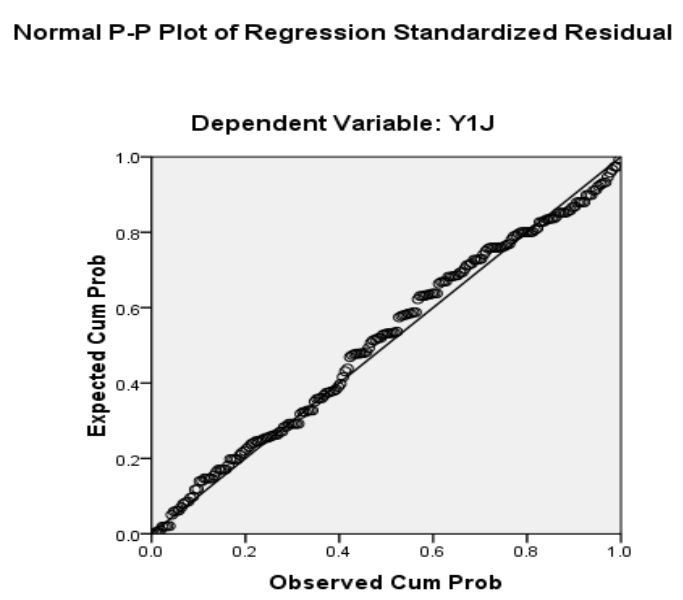

Gambar 1. Hasil Uji Normalitas Data

Berdasarkan hasil uji normalitas, maka data yang ada menyebar disekitar garis diagonal dan mengikuti arah garis diagonal, sehingga data dinyatakan memenuhi asumsi normalitas. Data kemudian dapat dianalisis leih lanjut dengan analisis Regresi Linier Berganda.

\section{Hasil Uji Asumsi Klasik}

Sebelum model yang ditemukan dalam Analisis Regresi Linier Berganda dapat dimaknai, maka model yang ada diuji menggunakan uji asumsi klasik. Uji asumsi klasik terdiri dari uji multikolinieritas. Hasil uji multokolinieritas adalah : 
Tabel 1. Hasil Uji Multikolinieritas

Sumber : lampiran 7

\begin{tabular}{|c|c|c|c|c|c|c|c|c|}
\hline \multirow[b]{2}{*}{ Model } & \multirow[b]{2}{*}{ Dimension } & \multirow[b]{2}{*}{ Eigenvalue } & \multirow[b]{2}{*}{ Condition Index } & \multicolumn{5}{|c|}{ Variance Proportions } \\
\hline & & & & (Constant) & $\mathrm{X} 1 \mathrm{~J}$ & $\mathrm{X} 2 \mathrm{~J}$ & $\mathrm{X} 3 \mathrm{~J}$ & $\mathrm{X} 4 \mathrm{~J}$ \\
\hline \multirow[t]{5}{*}{1} & 1 & 4.913 & 1.000 & .00 & .00 & .00 & .00 & .00 \\
\hline & 2 & .045 & 10.481 & .10 & .00 & .50 & .01 & .01 \\
\hline & 3 & . 021 & 12.193 & .07 & .00 & .32 & .79 & .00 \\
\hline & 4 & 016 & 13.363 & .05 & .95 & .16 & .09 & .01 \\
\hline & 5 & .005 & 12.388 & .78 & .04 & .02 & .11 & .98 \\
\hline
\end{tabular}

Hasil uji multikolinieritas penelitian dalam kolom condition index memiliki nilai 10,481; 12,193; 13,363; 12,388 sehingga dapat disimpulkan bahwa model regresi terbebas dari multikolinieritas.

\section{Hasil Uji Hipotesis}

Setelah data dinyatakan valid dan reliabel serta memenuhi asumsi normalitas, kemudian dilakukan hasil uji hipotesis. Data dianalisis menggunakan analisis regreasi linier berganda. Hasil uji hipotesis dijelaskan sebagai berikut :

Tabel 2 Hasil Analisis Regresi Linier Berganda (F test)

\begin{tabular}{|ll|c|c|c|c|c|}
\hline Model & & Sum of Squares & df & Mean Square & F & Sig. \\
\hline \multirow{2}{*}{1} & Regression & 275.219 & 4 & 68.805 & 34.455 & $.000^{\mathrm{a}}$ \\
& Residual & 389.401 & 195 & 1.997 & & \\
& Total & 664.620 & 199 & & & \\
\hline
\end{tabular}

Hasil uji $F$ test ( $F$ hit) penelitian ini sebesar 34,455 dengan tingkat signifikansi 0,000. Sedangkan nilai $\mathrm{F}$ tabel $(F \mathrm{tab})$ yang diperoleh melalui Tabel Nilai Distribusi $F$ (pada $\alpha=0,1$ ) adalah 1,940. Berdasarkan kriteria yang ada, maka dapat disimpulkan bahwa nilai $F$ hitung lebih besar dari $F$ tabel $(F$ hit $>F$ tab) maka Ho ditolak dan Ha diterima, Artinya Ada pengaruh kondisi sosial ekonomi orang tua terhadap tingkat pendidikan anak di Kabupaten Jember.

Tabel 3 Hasil Analisis Regresi Linier Berganda ( $t$ test)

\begin{tabular}{|l|c|c|c|c|c|}
\hline \multirow{2}{*}{ Model } & \multicolumn{2}{|c|}{ Unstandardized Coefficients } & \multicolumn{1}{c|}{$\begin{array}{c}\text { Standardized } \\
\text { Coefficients }\end{array}$} & & \\
\cline { 2 - 4 } & $\mathrm{B}$ & Std. Error & Beta & $\mathrm{t}$ & Sig. \\
\hline $1 \quad$ (Constant) & 7.073 & .878 & & 8.051 & .000 \\
X1J & .184 & .056 & .258 & 3.256 & .001 \\
X2J & .142 & .073 & .150 & 1.943 & .054 \\
X3J & .185 & .082 & .179 & 2.252 & .025 \\
X4J & .196 & .089 & .173 & 2.205 & .029 \\
\hline
\end{tabular}

Nilai $t$ test ( $t$ tabel) pada level of significant 0,1 pada penelitian ini sebesar 1,650 dengan tingkat signifikansi 0,100 (sig < 0,1). Hasil uji t test dalam penelitian ini dijelaskan sebagai berikut : 


\section{JURNAL NUSAMBA VOL.3 NO.1 APRIL 2018}

Tabel 4 Hasil uji hipotesis minor (t test)

\begin{tabular}{|c|c|c|c|}
\hline $\begin{array}{l}\text { Hipotesis } \\
\text { Minor ke - }\end{array}$ & Hasil Uji Hipotesis & Kriteria Hipotesis & Kesimpulan \\
\hline 1 & $\begin{array}{l}t \text { hitung } \rightarrow 3,256 \\
\operatorname{sig} \rightarrow 0,001\end{array}$ & $\begin{array}{l}t \text { tabel } \rightarrow 1,650 \\
\text { sig } \rightarrow 0,1\end{array}$ & $\begin{array}{l}\mathrm{t} \text { hitung }>\mathrm{t} \text { tabel dan } \\
\text { nilai sig }<0,1 \text { dapat } \\
\text { disimpulkan bahwa Ho } \\
\text { ditolak dan Ha diterima. } \\
\text { Artinya, ada pengaruh } \\
\text { tingkat pendidikan } \\
\text { orang tua terhadap } \\
\text { tingkat pendidikan anak } \\
\text { di Kabupaten Jember }\end{array}$ \\
\hline 2 & $\begin{array}{l}t \text { hitung } \rightarrow 1,943 \\
\operatorname{sig} \rightarrow 0,054\end{array}$ & $\begin{array}{l}t \text { tabel } \rightarrow 1,650 \\
\operatorname{sig} \rightarrow 0,1\end{array}$ & $\begin{array}{l}\mathrm{t} \text { hitung }>\mathrm{t} \text { tabel dan } \\
\text { nilai sig }<0,1 \text { dapat } \\
\text { disimpulkan bahwa Ho } \\
\text { ditolak dan Ha diterima. } \\
\text { Artinya, ada pengaruh } \\
\text { pendapatan orang tua } \\
\text { terhadap tingkat } \\
\text { pendidikan anak di } \\
\text { Kabupaten Jember }\end{array}$ \\
\hline 3 & $\begin{array}{l}t \text { hitung } \rightarrow 2,252 \\
\operatorname{sig} \rightarrow 0,025\end{array}$ & $\begin{array}{l}t \text { tabel } \rightarrow 1,650 \\
\operatorname{sig} \rightarrow 0,1\end{array}$ & $\begin{array}{l}\mathrm{t} \text { hitung }>\mathrm{t} \text { tabel dan } \\
\text { nilai sig }<0,1 \text { dapat } \\
\text { disimpulkan bahwa Ho } \\
\text { ditolak dan Ha diterima. } \\
\text { Artinya, ada pengaruh } \\
\text { kepemilikan fasilitas } \\
\text { terhadap tingkat } \\
\text { pendidikan anak di } \\
\text { Kabupaten Jember }\end{array}$ \\
\hline 4 & $\begin{array}{l}t \text { hitung } \rightarrow 2,205 \\
\text { sig } \rightarrow 0,029\end{array}$ & $\begin{array}{l}t \text { tabel } \rightarrow 1,650 \\
\operatorname{sig} \rightarrow 0,1\end{array}$ & $\begin{array}{l}\mathrm{t} \text { hitung }>\mathrm{t} \text { tabel dan } \\
\text { nilai sig }<0,1 \text { dapat } \\
\text { disimpulkan bahwa Ho } \\
\text { ditolak dan Ha diterima. } \\
\text { Artinya, ada pengaruh } \\
\text { jenis tempat tinggal } \\
\text { terhadap tingkat } \\
\text { pendidikan anak di } \\
\text { Kabupaten Jember }\end{array}$ \\
\hline
\end{tabular}

\section{Model Analisis Regresi Linier Berganda}

Berdasarkan Tabel 4. maka hasil analisis regresi linier berganda menghasilkan model sebagai berikut :

$$
\mathrm{Y}=0,258 \mathrm{X} 1+0,150 \mathrm{X} 2+0,179 \mathrm{X} 3+0,173 \mathrm{X} 4
$$




\section{Pembahasan}

Berdasarkan hasil penelitian, maka pembahasan penelitian akan menjelaskan dan memaparkan tentang keterkaitan penelitian dengan teori dan penelitian terdahulu. Pembahasan penelitian dijelaskan sebagai berikut :

\section{Pengaruh Variabel Kondisi Sosial Ekonomi Orang Tua (X) terhadap Tingkat Pendidikan} Anak (Y)

Berdasarkan hasil penelitian, maka ada pengaruh kondisi sosial ekonomi orang tua terhadap tingkat pendidikan anak. Hal ini dibuktikan secara statistik dengan nilai hasil uji $F$ test (F hit) penelitian ini sebesar $F$ Hit $(34,455)>F$ tabel $(1,950)$ dengan tingkat signifikansi $0,000<0,1$. Hasil penelitian memperkuat temuan Oktama (2013) yang menyebutkan bahwa kondisi sosial ekonomi berpengaruh terhadap tingkat pendidikan anak keluarga nelayan di Kelurahan Sugihwaras Kecamatan Pemalang Kabupaten Pemalang.

\section{Pengaruh Variabel Tingkat Pendidikan Orang Tua (X1) terhadap Tingkat Pendidikan Anak} $(\mathbf{Y})$

Hasil penelitian ini, meyimpulkan bahwa ada pengaruh tingkat pendidikan orang tua terhadap tingkat pendidikan anak. Hal ini dibuktikan dengan hasil analisis statistik hasil $t$ test yang menunjukkan bahwa nilai $\mathrm{t}$ hitung $(3,256)>\mathrm{t}$ tabel $(1,650)$ dan nilai sig $(0,001)<0,1$. Berdasarkan jawaban responden yang tertuang dalam deskripsi hasil penelitian, penyebab tingkat pendidikan orang tua berpengaruh terhadap tingkat pendidikan anak antara lain adanya tingkat pendidikan orang tua yang tergolong memiliki pendidikan cukup tinggi. Sebesar 69\% dari responden merupakan lulusan pendidikan tingkat menengah atas/SMA/Sederajat dan $14,5 \%$ dari responden memiliki pendidikan tinggi/D3/S1. Kondisi tingkat pendidikan orang tua ini, berbanding lurus dengan tingkat pendidikan anak. Sebesar $47 \%$ responden penelitian menyebutkan bahwa tingkat pendidikan anak mereka merupakan lulusan D3/S1.

\section{Pengaruh Variabel Pendapatan (X2) terhadap Tingkat Pendidikan Anak (Y)}

Hasil penelitian ini, menyimpulkan bahwa ada pengaruh pendapatan orang tua terhadap tingkat pendidikan anak. Hal ini dibuktikan dengan hasil analisis statistik $t$ test yang menunjukkan bahwa nilai t hitung $(1,943)>\mathrm{t}$ tabel $(1,650)$ dan nilai sig $(0,054)<0,1$. Berdasarkan jawaban responden yang tertuang dalam deskripsi hasil penelitian beberapa penyebab pendapatn orang tua berpengaruh terhadap tingkat pendidikan anak antara lain

a. Adanya pendapatan orang tua yang tergolong memiliki pendapatan cukup tinggi. Sebesar $43 \%$ dari responden menyebutkan bahwa memiliki pendapatan gaji diatas Rp. 1.000.000. dan hanya 4,5\% saja, responden yang memiliki pendapatan gaji kurang dari Rp.500.000. 
b. Sebesar $35 \%$ responden memiliki tambahan penghasilan secara rutin tiap bulan. Adanya tambahan penghasilan ini akan menambah semangat dan kemampuan orang tua untuk menyimpan dan digunakan sewaktu - waktu jika dibutuhkan untuk keperluan pendidikan anak.

\section{Pengaruh Variabel Tingkat Kepemilikan Fasilitas/Kekayaan (X3) terhadap Tingkat}

\section{Pendidikan Anak (Y)}

Hasil penelitian menyimpulkan bahwa ada pengaruh tingkat kepemilikan fasilitas/ kekayaan orang tua terhadap tingkat pendidikan anak. Hal ini dibuktikan dengan hasil analisis statistik $t$ test dengan nilai $\mathrm{t}$ hitung $(2,252)>\mathrm{t}$ tabel $(1,650)$ dan nilai sig $(0,025)<0,1$. Berdasarkan jawaban responden yang tertuang dalam deskripsi hasil penelitian beberapa penyebab tingkat kepemilikan fasilitas/ kekayaan orang tua berpengaruh terhadap tingkat pendidikan anak antara lain sebesar 56,5\% responden memiliki barang elektronik berupa handphone, Radio, DVD, Televisi dan kulkas. Artinya, responden memiliki tingkat kekayaan yang cukup untuk memperoleh informasi tentang pentingnya pendidikan sehingga menggugah kesadaran untuk menyekolahkan anak hingga pendidikan tinggi. Sebesar $64 \%$ responden memiliki sepeda motor dan sebesar $8,5 \%$ responden memiliki penghasilan lain dengan memiliki rumah untuk kost. Kepemilikan fasilitas/ kekayaan orang tua dapat menunjang tingkat pendidikan anak.

\section{Pengaruh Variabel Jenis Tempat Tinggal (X4) terhadap Tingkat Pendidikan Anak (Y)}

Hasil penelitian ini menunjukkan bahwa ada pengaruh jenis tempat tinggal terhadap tingkat pendidikan anak. Hal ini dibuktikan dengan hasil analisis statistik $t$ test dengan nilai $\mathrm{t}$ hitung $(2,205)>\mathrm{t}$ tabel $(1,650)$ dan nilai sig $(0,029)<0,1$. Berdasarkan hasil jawaban responden yang tertuang dalam deskripsi hasil penelitian, beberapa penyebab jenis tempat tinggal berpengaruh terhadap tingkat pendidikan anak diantaranya bahwa 92,5\% responden yang memiliki anak dengan tingkat pendidikan yang tergolong tinggi memiliki rumah yang ditempati merupakan tempat tinggal permanen. Bahan dasar utnuk latai rumah juga terbuat dari keramik, jenis rumah yang ditempati juga sebagian besar bertipe 36 , serta kepemilikan rumah yang merupakan milik sendiri

\section{KESIMPULAN}

Berdasarkan hasil penelitian dan pembahasan, maka kesimpulan penelitian adalah sebagai berikut :

1. Ada pengaruh kondisi sosial orang tua terhadap tingkat pendidikan anak. Hal ini dibuktikan dengan hasil uji hipotesis yang menunjukkan bahwa nilai sebesar F Hit $(34,455)>\mathrm{F}$ tabel $(1,950)$ dengan tingkat signifikansi $0,000<0,1$. 
2. Ada pengaruh tingkat pendidikan orang tua terhadap tingkat pendidikan anak. Hal ini dibuktikan dengan hasil uji hipotesis nilai $t$ hitung $(3,256)>t$ tabel $(1,650)$ dan nilai sig $(0,001)<0,1$.

3. Ada pengaruh pendapatan orang tua terhadap tingkat pendidikan anak. Hal ini dibuktikan dengan hasil uji hipotesis nilai $t$ hitung $(1,943)>t$ tabel $(1,650)$ dan nilai sig $(0,054)<0,1$.

4. Ada pengaruh tingkat kepemilikan fasilitas/kekayaan terhadap tingkat pendidikan anak. Hal ini dibuktikan dengan hasil uji hipotesis nilai thitung $(2,252)>t$ tabel $(1,650)$ dan nilai sig $(0,025)$ $<0,1$.

5. Ada pengaruh jenis tempat tinggal terhadap tingkat pendidikan anak. Hal ini dibuktikan dengan nilai thitung $(2,205)>\mathrm{t}$ tabel $(1,650)$ dan nilai sig $(0,029)<0,1$.

\section{SARAN}

Berdasarkan kesimpulan, maka saran penelitian adalah sebagai berikut :

1. Kondisi sosial ekonomi orang tua berpengaruh terhadap tingkat pendidikan anak, artinya semakin baik kondisi sosial ekonomi orang tua, akan semakin tinggi tingkat pendidikan anak. Akan tetapi sebaliknya, semakin buruk kondisi sosial ekonomi orang tua, akan semakin rendah tingkat pendidikan anak. Berdasarkan kenyataan tersebut, perlu adanya sosialisasi tentang pentingnya pendidikan yang dilakukan oleh perangkat pemerintahan desa dengan harapan menggugah orang tua untuk menyekolahkan anak.

2. Setelah sosialisasi dilakukan, perlu adanya keterlibatan pemuda di desa setempat yang memiliki tingkat pendidikan tinggi, untuk membentuk forum seperti rumah belajar bagi siswa kurang mampu. Sehingga, masyarakat khususnya anak - anak tetap mendapatkan pendidikan yang layak.

3. Pemerintah juga perlu mendukung kegiatan yang saat ini digagas Pemerintah Kabupaten Jember, yaitu program sekolah gratis, dengan cara bekerjasama dengan orang tua melaporkan pada Dinas Pendidikan, tentang jumlah anak usia sekolah yang seharusnya mengenyam pendidikan namun putus ditengah jalan karena kurangnya biaya. Sehingga kondisi sosial ekonomi masyarakat yang tergolong buruk, tidak menghambat tingka pendidikan anak.

\section{DAFTAR RUJUKAN}

Badan Pusat Statistik Kabupaten Jember, 2013, Jember Dalam Angka

Reddy Zaki Oktama. 2013. Pengaruh Kondisi Sosial Ekonomi Terhadap Tingkat Pendidikan Anak Keluarga Nelayan Di Kelurahan Sugihwaras Kecamatan Pemalang Kabupaten Pemalang Tahun 2013. Tesis, Universitas Negeri Semarang.

Salmah. 2013. Pengaruh Status Sosial Ekonomi Keluarga Terhadap Motivasi Melanjutkan Ke Perguruan Tinggi di Mas Pontianak. Artikel penelitian, Universitas Tanjung Pura Puntianak. 
Sarwono. 2009. Statistik itu Mudah. Yogyakarta : Andi Offset.

Sugiyono. 2010. Metode Penelitian Administrasi. Bandung : Alfabeta.

Djaja, Sutrisno. 2004. Metodologi Penelitian Sosial. Universitas Jember 